Brit. J. industr. Med., 1960, 17, 304.

\title{
THE RELATIONSHIP OF BYSSINOSIS TO THE BACTERIA AND FUNGI IN THE AIR OF TEXTILE MILLS
}

\author{
BY \\ PETER TUFFNELL*
}

From the Departments of Bacteriology and Occupational Health, The University of Manchester

(RECEIVED FOR PUBLICATION MAY 4, 1960)

The principal causative agent of byssinosis lies in the dust of cotton mills. This dust contains bacteria and fungi. An attempt has been made to determine whether any association could be established between the numbers of viable bacteria and fungi in the air of two cotton and two jute mills, and the prevalence of byssinosis. No association was found except between the numbers of live organisms of $B$. pumilus and $B$. subtilis, and the occurrence of byssinosis. This association does not establish a causal relationship, but it is suggested that an attempt should be made to produce typical symptoms in byssinotic subjects by means of organisms of the genus Bacillus. A subsequent paper presents the results of some observations of this kind.

It is generally accepted that the causative agent of byssinosis lies in the dust produced during the preparation of cotton for spinning. This dust contains fragments of the cotton plant, bacteria, fungi, and mineral salts, and silica derived from the soil. Bacteria and fungi have been shown to occur in high concentrations in the air of cardrooms (Drummond and Hamlin, 1952) and must be suspected when considering the possible aetiology of byssinosis. Thiry (1941), for example, has suggested that moulds and bacteria are the cause of the disease in flax workers. Since there is no evidence that byssinosis is an infection, both dead and live organisms should be considered. Attempts to estimate the total concentration of organisms by microscopic examination of the dust from the air of textile mills proved too unreliable to be of value owing to admixture with other materials. With direct studies upon byssinotic subjects as the ultimate aim, the investigation, described in this paper, was instituted to see whether there was a relationship between the concentration of live organisms in the air and the incidence of byssinosis.

\section{Method}

Mills Investigated.- Two cotton mills (A and B), in which the incidence of byssinosis in the cardrooms had been determined, were selected for study. A was a cotton

* Present address: Department of Laboratories, Toronto General Hospital, Toronto 2, Canada. mill spinning coarse counts of cotton; $B$ a cotton mill spinning fine counts of Egyptian cotton. A was more dusty than $B$. The total dust concentrations measured gravimetrically by the Hexhlet apparatus have already been published (Roach and Schilling, 1960).

Two jute mills (C and D) were also selected. Dust concentrations, measured with a thermal precipitator, showed that mill $\mathrm{C}$ had a mean dust count of 325 particles per $\mathrm{ml}$. The corresponding figure for mill D was 182.

The part of the mill selected for study was the cardroom where the fibres are opened and combed preparatory to spinning. This is the dustiest process in the mill and Schilling (1956) has shown that it has the highest incidence of byssinosis.

Sampling.-The concentration of live micro-organisms in the air was determined by means of a slit sampler and by a Hexhlet apparatus (Wright, 1954).

With the very high concentrations found, the ordinary method of using a slit sampler, by exposing nutrient agar plates, although reducing the sampling time to a few seconds was found to produce overcrowding of the colonies and the following modification of the method was therefore devised.

The petri dishes were prepared with a thin layer of $1 \%$ agar in tap water. Each dish was exposed in the sampler for 30 minutes when the agar was removed and transferred to a jar packed in ice. Plates were exposed successively for a total sampling time of three to four hours. In this way a sample was obtained representative of the concentration during the day.

The total mixed specimen, at the completion of sampling was homogenized in approximately $100 \mathrm{ml}$. 
saline (measured after mixing, in order to include saline needed to wash out the container) in an Atomix* at half speed (6,000 r.p.m.) for three minutes and then inoculated on to the surface of appropriate solid media. If necessary the agar mixture was diluted. The extent of this dilution and the volume to be inoculated were determined by preliminary trial with other samples from the same source.

The Hexhlet apparatus sucked air through a filterpaper disc and was run for the whole of the working day. The filter paper was macerated in the Atomix and inoculated on to plates in a similar manner to the homogenized agar.

Media.-The medium used for culturing bacteria was a meat extract peptone-agar, which, after pouring, was dried for two hours in a $37^{\circ} \mathrm{C}$. incubator to prevent spreading of colonies. The inoculum was spread evenly over the surface and plates were incubated for 24 hours at $37^{\circ} \mathrm{C}$. and for 24 hours at $22^{\circ} \mathrm{C}$., when the colonies were counted. Twelve plates were used for each determination and the number of colonies per plate was usually between 50 and 200 . It was found advisable to restrict the volume of inoculum to a maximum of $0.25 \mathrm{ml}$., as larger volumes tended to induce spreading of some colonies.

The medium used for culturing fungi consisted of a dextrose-peptone-agar base with $1: 30,000$ Rose Bengal and $30 \mu \mathrm{g} . / \mathrm{ml}$. streptomycin (Martin, 1950). It was only necessary to dry the plates sufficiently to remove excess moisture. These plates were incubated at $22^{\circ} \mathrm{C}$. for three days. As with the bacteria, 12 plates were used for each determination and they contained a similar number of colonies. A larger volume of inoculum could be used for fungi than for bacteria but it was found to be inadvisable to exceed $1 \mathrm{ml}$., as larger volumes were not always completely absorbed.

Evaluation of Method.-In the course of the investigation a comparison was made between the results obtained with the slit sampler used in the manner described (homogenizing method) and the standard method using nutrient agar plates. A site was chosen where the concentration of air-borne organisms was sufficiently low to produce well-separated colonies with the standard method and a sampling time of five minutes.

The dispersion of bacterial aggregates by the homogenizing method increased the count by a factor ranging from 3.9 to 7.4 with a mean of 5.3 (Table 1 ).

A comparison was also made between the results of counting bacteria by the slit sampler homogenizing technique and by using the Hexhlet apparatus.

Five samples taken in the cardroom of mill B with the Hexhlet gave a mean of 2,800 organisms per cu. $\mathrm{ft}$. while seven samples with the slit sampler gave a mean of 3,300. The lower count given by the Hexhlet may well be due to the desiccating effect of the air flow through the apparatus, which was $100 \mathrm{l} . / \mathrm{min}$. for a sampling time of nine hours, or to a difference in the efficiency of dispersing clumps of bacteria depending on whether they were on an agar gel or on filter paper.

\footnotetext{
* Measuring and Scientific Equipment Co., London.
}

TABLE 1

VIABLE BACTERIA IN A COMBING ROOM ESTIMATED BY A SLIT SAMPLER

(Organisms per cu. ft.)

\begin{tabular}{c|c|c}
\hline $\begin{array}{c}\text { Homogenizing } \\
\text { Method }\end{array}$ & $\begin{array}{c}\text { Standard } \\
\text { Method }\end{array}$ & $\begin{array}{c}\text { Ratio } \\
\text { H/S }\end{array}$ \\
\hline 448 & 61 & $7 \cdot 4$ \\
748 & 102 & 7.3 \\
358 & 82 & 4.4 \\
331 & 84 & 3.9 \\
627 & 123 & $5 \cdot 1$ \\
811 & 89 & 4.6 \\
\hline
\end{tabular}

\section{Results}

The concentration of viable micro-organisms in the cardrooms of all four mills was very high (Table 2).

The highest mean figures (bacteria plus fungi) were in the jute mill $C$ and the mill spinning coarse cotton $\mathrm{A}$; the lowest were in the cotton mill spinning fine counts $B$ with the jute mill $D$ in an intermediate position. There was considerable variation from day to day in any one site.

In all cases the bacteria outnumbered the fungi, the commonest bacteria being those of the genus Bacillus. Within this genus the species differed in the two types of mill, B. subtilis and $B$. pumilus being the only species found in the cotton mills, while $B$. megaterium predominated in the jute mills (Table 3).

The fungi were mainly of the genera Aspergillus and Penicillium, the highest numbers being in the jute mills. Actinomycetes were found in particularly high concentrations in jute mill $\mathrm{C}$.

\section{Discussion and Conclusions}

In the cotton mill $A, 72$ of the 135 cardroom workers had symptoms of byssinosis whilst in B only five of the 32 at risk were so affected. Although previous investigations (Schilling, 1956), had failed to reveal byssinosis in jute workers it appeared possible that three of the 16 workers at risk in the jute mill $C$ and one of 14 in $D$ might have mild manifestations of the disease. Thus it was presumed that the incidence of byssinosis throughout the four mills investigated ranged from a high prevalence in $\mathbf{A}$ down to virtual absence in $\mathbf{D}$.

No association was established between the total concentration of live micro-organisms in the atmosphere and the incidence of byssinosis. In cotton mill $\mathrm{A}$ and jute mill $\mathrm{C}$ the concentration was similar and approximately 10 times greater than that in $B$. Nor did there appear to be any relation between either the total number of bacteria or the total number of fungi present in the atmosphere and the prevalence of byssinosis. The occurrence of 
TABle 2

\begin{tabular}{|c|c|c|c|c|c|c|}
\hline \multirow{3}{*}{ Mill } & \multicolumn{3}{|c|}{ Bacteria } & \multicolumn{3}{|c|}{ Fungi } \\
\hline & \multirow{2}{*}{ No. of Readings } & \multicolumn{2}{|c|}{ No. per cu. ft. } & \multirow{2}{*}{ No. of Readings } & \multicolumn{2}{|c|}{ No. per cu. ft. } \\
\hline & & Range & Mean & & Range & Mean \\
\hline $\mathbf{A}$ & 12 & $\begin{array}{l}20,200 \\
70,300\end{array}$ & 36,400 & 2 & $\begin{array}{l}1,900 \\
2,650\end{array}$ & 2,300 \\
\hline B & 7 & $\begin{array}{r}2,500 \\
3,900\end{array}$ & 3,300 & 2 & $\begin{array}{r}4,050 \\
485\end{array}$ & 510 \\
\hline C & 7 & $\begin{array}{l}3,000 \\
61,000\end{array}$ & 32,400 & 3 & $\begin{array}{r}4,700 \\
13,000\end{array}$ & 8,817 \\
\hline $\mathbf{D}$ & 3 & $\begin{array}{r}2,300 \\
3,600\end{array}$ & & 2 & $\begin{array}{r}15,000 \\
730 \\
3,300\end{array}$ & 2,000 \\
\hline
\end{tabular}

TABLE 3

VIABLE ORGANISMS PER CUBIC FOOT OF AIR

\begin{tabular}{|c|c|c|c|c|c|c|c|c|c|c|}
\hline Mill & $\begin{array}{c}\text { Total } \\
\text { Organisms }\end{array}$ & $\begin{array}{c}\text { Total } \\
\text { Bacteria }\end{array}$ & $\begin{array}{c}\text { Total } \\
\text { Bacillus } \\
\text { Species }\end{array}$ & $\begin{array}{c}\text { B. pumilus } \\
+ \\
\text { B. subtilis }\end{array}$ & $\begin{array}{c}\text { B. Mega- } \\
\text { terium }\end{array}$ & $\begin{array}{l}\text { Micro- } \\
\text { coccus }\end{array}$ & $\begin{array}{c}\text { Actino- } \\
\text { myces }\end{array}$ & $\begin{array}{c}\text { Total } \\
\text { Fungi }\end{array}$ & Aspergilli & Penicillium \\
\hline $\begin{array}{l}\mathbf{A} \\
\mathbf{B} \\
\mathbf{C} \\
\mathbf{D}\end{array}$ & $\begin{array}{r}38,700 \\
3,800 \\
41,217 \\
5,090\end{array}$ & $\begin{array}{r}36,400 \\
3,300 \\
32,400 \\
3,090\end{array}$ & $\begin{array}{r}27,700 \\
3,000 \\
12,000 \\
1,518\end{array}$ & $\begin{array}{r}27,700 \\
3,000 \\
1,900 \\
188\end{array}$ & $\begin{array}{r}\overline{-} \\
\begin{array}{r}10,000 \\
1,330\end{array}\end{array}$ & $\begin{array}{r}6,550 \\
160 \\
4,540 \\
806\end{array}$ & $\begin{array}{r}2,190 \\
0 \\
15,850 \\
494\end{array}$ & $\begin{array}{r}2,300 \\
510 \\
8,817 \\
2,000\end{array}$ & $\begin{array}{r}700 \\
260 \\
2,210 \\
480\end{array}$ & $\begin{array}{r}400 \\
240 \\
5,640 \\
1,320\end{array}$ \\
\hline
\end{tabular}

individual genera was also haphazard with the exception of the genus Bacillus. There appeared to be definite association between the incidence of byssinosis and the number of live organisms of $B$. pumilus and $B$. subtilis. This does not necessarily establish a causal relationship between the two. Furthermore, since byssinosis is not an infection, not only should dead as well as live micro-organisms be considered but also the by-products of growth, and whether they are in the spore or vegetative stage. Thus the amount of bacterial or fungal substance in dust which originates from a particular species and which might be concerned in causing byssinosis is not necessarily indicated by the viable count of that organism.

In view of the difficulty in interpreting the results it would seem that there is little to be gained by further examination of cardroom dust for microorganisms. The next and essential step is to attempt to produce typical symptoms in byssinotic subjects under controlled conditions. It is in this way that the causal relationship of a particular material to byssinosis may best be investigated. The present investigation has suggested that the genus Bacillus should be tested in such direct investigation. A further paper presents the results of some observations of this kind (Tuffnell, 1960).

I wish to thank Professor H. B. Maitland and Dr. R. S. F. Schilling for suggesting this investigation and for constant assistance; also Professor W. J. Tulloch for hospitality in Dundee, Dr. D. G. Drummond for the loan of a slit sampler and Dr. R. E. O. Williams and Surgeon Commander H. M. Darlow for the loan of other instruments. Mr. S. A. Roach provided the Hexhlet samples.

I am much indebted to Professor R. E. Lane and Miss I. Dingwall-Fordyce. Finally, without the cooperation of the mill managements this investigation would not have been possible.

\section{REFERENCES}

Drummond, D. G., and Hamlin, M. (1952). Brit. J. industr. Med., 9, 309 .

Martin, J. P. (1950). Soil Sci., 69, 215.

Roach, S. A., and Schilling, R. S. F. (1960). Brit. J. industr. Med., Schilling, 1 .

Schilling, R. S. F. (1956). Lancet, 2, 261 and 319.

Thiry, U. (1941). Arch. Mal. prof., 3, 129.

Wright, B. M. (1954). Ibid., 11, 284. 